\title{
Introduction: Cultural Convergence at Dublin's Gate Theatre
}

Ondřj Pilný, Rund van den Beuken, and Ian R. Walsh

In his autobiography All for Hecuba (1946, 1961), Micheál mac Liammóir describes the shared excitement that Hilton Edwards, Desirée ‘Toto' Bannard Cogley, Gearóid Ó Lochlainn and he himself felt during the summer of 1928 as they were setting up the Dublin Gate Theatre Studio (as their new venture was initially called), while he also recounts his surprise at the broader interest that they were generating: 'Miraculously, there seemed many Dubliners who desired to see plays by Ibsen and Evreinov and O'Neill, and the guineas began to shower upon us.' (60) Although such auspicious enthusiasm was important to the

\author{
O. Pilný $(\bowtie)$ \\ Charles University, Prague, Czech Republic \\ e-mail: pilnoaff@ff.cuni.cz \\ R. van den Beuken \\ Radboud University Nijmegen, Nijmegen, The Netherlands \\ e-mail: r.vandenbeuken@let.ru.nl \\ I. R. Walsh \\ National University of Ireland, Galway, Ireland \\ e-mail: ian.walsh@nuigalway.ie \\ (C) The Author(s) 2021 \\ O. Pilný et al. (eds.), Cultural Convergence, \\ https://doi.org/10.1007/978-3-030-57562-5_1
}


Gate's early success, producing foreign avant-garde theatre would not prove particularly lucrative, and it was not until Lord Edward Longford offered to buy the remaining shares in late 1930 that the company could be kept afloat. By that time, Edwards and mac Liammóir had indeed already produced plays from Norway (Ibsen, Wiers-Jenssen), Sweden (Strindberg), Denmark (Bramsen), Russia (Evreinov, Tolstoy), Germany (Goethe, Kaiser), Czechoslovakia (Čapek), France (Raynal), Spain (Martínez Sierra) and the US (O’Neill, Greensfelder, Rice).

The Gate's outward gaze not only increased the influx of experimental plays from the Continent and America to Ireland, but also inspired Irish dramatists to revolutionize their dramaturgy. Such new creations could hold their own with Abbey productions: for example, four out of the total of eight dramas included by Curtis Canfield in his anthology Plays of Changing Ireland (1936) were original works by Denis Johnston, Edward Longford, Christine Longford and Mary Manning produced at the Gate. Canfield described how '[i]n the midst of this stirring of new forces another Ireland is emerging, one which, if early symptoms are correct, is more than content to allow its romantic predecessor to remain with O'Leary in the grave' (xii). The anthology was presented as an attempt at charting the cosmopolitanism of new Dublin playwrights, whom Canfield considered to be intent either on dramatizing the diversified life of the modern Europeanized capital, or on revealing, with heartening sincerity, the effect which strange and unfamiliar conditions are having on Irish character' (xii).

The early Gate, then, was instrumental in facilitating cultural convergence, both in Ireland and on its many tours abroad, which included visits to Cairo, Alexandria, Malta, Athens, Ljubljana, Zagreb, Belgrade, Salonika, Sofia, and Bucharest in the 1930s alone. After World War II, Edwards - mac Liammóir Productions also toured the US and Canada, performed Hamlet at Elsinore Castle in Denmark and returned to Egypt and Malta. Despite these many international links, the collaborations and exchanges that mark the Gate's pivotal role in the Irish theatre scene have only been partially explored. Much of the major writing on the theatre until more recently was of a biographical or commemorative nature. Most prominent amongst these books are Christopher Fitz-Simon's seminal double biography of Hilton Edwards and Micheál mac Liammóir entitled The Boys $(1994,2002)$ and Richard Pine and Richard Allen Cave's book The Gate Theatre 1928-1978 (1984) that accompanied the fiftieth 
anniversary celebration of the theatre. However, as Irish theatre scholarship has begun to draw on new methodologies and frameworks beyond postcolonial analysis that privileged the work of the playwright, the Gate has come to enjoy more sustained examination. The work of the early Gate is particularly prominent in studies on modernism and modernity on stage in Ireland. Ben Levitas's chapter in Cambridge Companion to Irish Modernism (2014) is exemplary of such work. It charts a history of modernist theatrical experiments in Ireland from Oscar Wilde to Marina Carr that resisted 'routine mimesis' (111), favouring stylizations that were socially and politically self-reflexive but never fixed in their theatricality. Levitas situates the early expressionist productions of Eugene O'Neill, Elmer Rice, Karel Čapek and Georg Kaiser at the Gate, renowned for Edwards's innovative direction and mac Liammóir's evocative designs, in this modernist tradition. He then considers Denis Johnston's The Old Lady Says 'No'! (1929) as an example of 'a native expressionist' (120) work, discusses the Gate's regular productions of Wilde in relation to the founders' commitment to theatricality and their relevance to their own homosexuality and also commends the theatre for its championing of Mary Manning's satirical Youth's the Season-? (1931).

This pattern is repeated in lengthier essays in The Oxford Handbook of Modern Irish Theatre (2016), where Richard Cave dedicates a great deal of his chapter, 'Modernism and Irish Theatre 1900-1940', to examining the early expressionistic productions of Edwards and mac Liammóir (The Old Lady Says 'No'! in particular) in similar terms to Levitas. Paige Reynolds charts the technical achievements in these same early productions in her chapter, 'Direction and Design to 1960', while Éibhear Walshe interrogates the supposedly radical nature of Gate productions of Wilde, from its foundation to the present, finding that the theatricality present in the productions depicted Wilde more as a 'charming dandy' (217) rather than a troubling queer artist. How expressionism offered women a stylistic vocabulary to disrupt patriarchal naturalism is considered in the work of Mary Manning and Maura Laverty at the Gate by Cathy Leeney in her chapter 'Women and Irish Theatre before 1960'. Chris Morash's chapter marks a departure in its spatial analysis of the Gate Theatre building but returns to framing this analysis in relation to how the space created 'a kind of enforced modernity' (432). Performances at the Gate in the post-1960 period are referenced in many chapters on playwrights, actors, directors and designers in the handbook, but those exceed the scope of the current study. 
This is true also of the Palgrave Handbook of Contemporary Irish Theatre and Performance (2018), which features many chapters that focus on work at the Gate in the contemporary period, in particular productions of G.B. Shaw, Brian Friel, Samuel Beckett and Frank McGuinness. The international tours of Gate productions from the 1980s onward are the subject of a chapter-long study by Mária Kurdi. Despite this handbook taking the post-World War II era as its starting point, it considers that 'it is only since the late 1950s and early 1960s that a significant new generation of writers emerged' (8). As a result, there is little reflection on the early Gate and its influence and disappointingly little on the theatre in the 1950s.

However, 2018 saw the publication of The Gate Theatre, Dublin: Inspiration and Craft, the first book-length collection of essays on the Gate. The chapters in this volume encompass a full history of the theatre from its foundation to the contemporary period. It redirects the discussion of the Gate away from modernism towards a sustained interrogation of its complex relationship with nationalism and also stands as a major act of historical recovery, remembering the contributions of the producer 'Toto' Cogley, the actor Ria Mooney and the plays of Lord Edward and Lady Christine Longford, as well as offering more detailed analysis of Johnston's and Manning's dramas, Edwards's achievements as a director and mac Liammóir's as a playwright. Ruud van den Beuken's recent monograph Avant-Garde Nationalism at the Dublin Gate Theatre, 1928-1940 (2020) further engages with the company's attempts to promote new Irish playwrights and to facilitate collective identity formation by engaging with contentious issues in both the nation's history and in the contemporary Free State, such as the legacy of the Easter Rising, class identities and sectarian tensions.

Despite all these recent publications, there are still numerous lacunae in the existing scholarship. These include, surprisingly, the writings on theatre of its original artistic directors, Micheál mac Liammóir and Hilton Edwards, which elucidate the aesthetic and theatrical practice of the Gate against the backdrop of the considerable international experience of both partners. It is particularly in this context that comparisons of the Gate's work with European theatres with a similar focus and remit are remarkably scarce; likewise, comparative studies are lacking of the productions of international drama (e.g., German, British, American or Czech plays) at the Gate and in their original contexts, as are discussions of design or the Gate's poetics in an international or intercultural context. Moreover, 
the influence of cinema on the work of the Gate (including its repertoire and its promotion) remains unexplored. Finally, there are numerous neglected figures associated with the Gate waiting to receive appropriate critical attention, such as its co-founder Gearóid Ó Lochlainn - an actor and Irish-language playwright whose work helps to further elucidate the involvement of the Gate in the development and promotion of Irishlanguage theatre, or prominent women playwrights, including Christine Longford, who was also indispensable for the theatre's management. It is by addressing these neglected areas that this volume intends to unravel the complex cultural convergences at the Dublin Gate Theatre in its first three decades of existence, showing the Gate to have been a truly cutting-edge theatre of its time in international terms.

In their consummate professionalism, Edwards and mac Liammóir meticulously documented production details in prompt scripts, set and costume designs, lighting plots, photographs and sketches. Such ephemera was kept and valued as the theatre often relied financially upon the revival of successful productions, but also because Edwards and mac Liammóir persisted together through the decades, eventually passing on a legacy that continued under the directorship of Michael Colgan and on to Selina Cartmell in the present. This longevity of the Gate is a rarity in the history of independent avant-garde theatres, which often die with their founders or whose artistic vision and practices change radically under regular successive changes in management. The archival holdings on the theatre at the Gate Theatre Archive at Northwestern University (Evanston, IL) and in the Gate Theatre Digital Archive at NUI Galway are thus exceptionally rich in the amount of detail that they preserve. The present volume offers a sampling of those riches by way of various images, illustrating the potential for the detailed reconstruction of the work of directors and designers of individual shows in particular. Indeed, contributors to this collection have all drawn on these abundant archival materials in their analysis of the theatre.

No less importantly, focusing on cultural convergences means that the output of the Gate Theatre is examined in terms of the dynamics of exchange, interaction and acculturation that reveal the workings of transnational infrastructures. Our conception of cultural convergence differs from that of George Ritzer's popular definition of this term as a process whereby 'cultures tend to grow similar to one another after being subjected to the same cultural flows' (154). In the Gate's productions, practitioners' backgrounds and writings on theatre, there is a constant 
coming together of different cultures; but the focus of this study is on how these meetings of cultures offered variety and novelty as much as similarity. Ritzer's notion of cultural convergence moves towards a fixed endpoint of sameness, whereas the essays in this collection mark processes of cultural convergence as continual interactions that are enlivened by difference. However, the volume has been envisioned primarily as a work of theatre history based on archival research; as such, it proceeds from newly acquired sources towards a broader contextualization and theorization of the dynamics at hand, rather than starting with a preconceived theoretical framework and attempting to make the results of archival research fit such a framework. The conception of cultural convergence that emerges from the research conducted in these essays thus allows for our contributors to employ a multitude of differing perspectives on the material and utilize a variety of theoretical concepts including transnationalism, internationalism, interculturalism and cosmopolitanism.

In employing such an approach, this volume is situated within a growing area of scholarship that moves away from the once dominant consideration of Irish theatre in postcolonial terms to an exploration of wider global contexts. In this sense, the essays in this collection build particularly on the work of Patrick Lonergan, Charlotte McIvor, Wei $\mathrm{H}$. Kao and Jason King amongst others. The majority of scholarship in this area has tended to focus on Irish theatre from the 1960s to the contemporary, with some studies also looking at the work of seminal figures of the Irish revival such as Yeats, Synge and Gregory. These studies map onto the historical narrative that characterizes the period after the revival and before the economic expansionist policies of the 1960s as artistically fallow due to the cultural isolation of Ireland created by nationalistic policies of self-sufficiency and the rise of Catholic conservatism. What is unfortunately forgotten in this perspective is that the manifold creative efforts of the early Gate Theatre were energized by its commitment to cosmopolitanism. The present collection addresses this neglect by concentrating on the early history of the Gate Theatre from 1928 to 1960 , which is remarkable for running counter to the narrowminded xenophobic nationalism of the era. The book thus aims to be not only an important project of retrieval, but also an intervention in the study of Irish theatre that challenges prevailing historical periodization, charting a continuous narrative of fruitful artistic engagement with international cultures through the work of the Gate Theatre under the artistic directorate of Micheál mac Liammóir and Hilton Edwards. 
In establishing this scope, it must be noted that mac Liammóir and Edwards's creative energies became somewhat dissipated after the première of mac Liammóir's famous one-man show The Importance of Being Oscar (1960), with which he proceeded to tour the world, and Edwards's acceptance of the post of Head of Drama at RTÉ in 1961. It may be argued that the only productions of major significance that occurred at the Gate from this point until the death of its founding directors (1978 and 1982, respectively) were Saint Joan of the Stockyards by Bertolt Brecht (1961), and the celebrated early stagings of Brian Friel in the 1960s; however, these have been amply covered by other scholars, thereby marking 1960 as a natural terminus for this collection.

The next chapter of this book lays out in detail the views of Hilton Edwards and Micheál mac Liammóir on theatre, and as such provides a general point of reference not only for the discussion of the Gate's productions further in the volume, but also of its artistic policies and the nature of its programming. Both Edwards and mac Liammóir wrote and gave talks about their work at the Gate on the one hand and about theatre's past and present on the other throughout their artistic careers, and their individual views have been reasonably well covered by scholars (for Edwards, see, e.g., Walsh; for mac Liammóir, see, e.g., Ó hAodha). However, their respective commentaries on theatrical styles, design, acting and directing have almost exclusively been discussed separately, as much of what mac Liammóir wrote about theatre was in the Irish language and has been available only to the speakers of the language. Joan FitzPatrick Dean and Radvan Markus's essay presents a pioneering collaborative study in which the writings of the original artistic directors of the Gate are treated in a comparative fashion, teasing out the dynamics of their perspectives, revealing the intersections of Edwards's reflections on continental experimentalism with mac Liammóir's vision on the prospects of Irish-language drama. It is in their reservations about realism, the desire for theatre to be truly theatrical and the wide-ranging internationalism with which they proceeded to develop Irish theatre that the confluence of opinion is most remarkable. Moreover, Dean and Markus's chapter illustrates that the influence of Edwards and mac Liammóir has been as significant in English-language theatre in Ireland as in theatre in the Irish language.

While the passion for, and fluency in, the Irish language on the part of Micheál mac Liammóir is a well-established fact, the figure of another Irish-speaking founder of Dublin's Gate Theatre, Gearóid Ó Lochlainn 
(1884-1970), is familiar only to a small circle of Irish-language specialists. Pádraig Ó Siadhail makes a seminal act of reclamation in his chapter for this remarkable actor, playwright and theatre activist, outlining not only Ó Lochlainn's work for and at the Gate, but also his principal role in An Comhar Drámuíochta which the Gate hosted for four seasons in 1930-1934, his work as an actor, director and translator in further prominent Irish-language companies, and his appearance in plays in English in Dublin's other theatres, including the Abbey and the Pike Theatre Club. Moreover, Ó Siadhail highlights the international experience that Ó Lochlainn brought to the Gate, as his acting skills were honed in Denmark in the 1910s, first in silent films and later as a company member of the Alexandrateatret in Copenhagen. The notion of two gay Englishmen, an Irish-language revivalist and representative of Sinn Féin in Denmark, and a radical French socialist - the cabaret manager and actor Desirée Bannard Cogley - as the founding artistic figures of a major theatre project in Free State Ireland, dominated as it already was by the influence of the Catholic Church, might appear beyond the realm of the plausible, certainly from the perspective of earlier theatre historiography and its focus on the hegemonic. This unlikely confluence perhaps explains the disappearance of Ó Lochlainn and Bannard Cogley from the narrative of the Gate Theatre. However, Ó Siadhail's painstaking research on Ó Lochlainn's career, together with other recent pioneering essays, such as Elaine Sisson's work on Madame Bannard Cogley (Sisson 2018), complement Fitz-Simon's biography of Edwards and mac Liammóir in recovering the Dublin of the 1920 s and 1930s in its extraordinary cultural variety and plasticity, thus adding to the magnificently evocative and no less surprising picture of the three preceding decades painted several years ago by Roy Foster in Vivid Faces (2014).

The next chapter represents another unique collaboration, this time between a theatre scholar and a professional genealogist. David Clare and Nicola Morris have plunged deep into archives in order to examine the mixed background of four prominent figures at the Gate: Hilton Edwards and Micheál mac Liammóir, the theatre's 'leading lady' Coralie Carmichael, and the actor, costume designer and milliner Nancy Beckh. They bring to light much new information about the family histories, not least about the 'doctored' origins of mac Liammóir on the one hand and the so far largely unexplored background of Edwards on the other. Using a new interculturalist approach, they argue that the transnational roots of these artists - Scottish and Moroccan in the case of Carmichael, and 
German and English in the case of Beckh - helped them create sensitive and subtle 'intercultural performances' in their work, rather than engaging them in shallow cosmopolitanism or cultural imperialism in Ireland.

Charlotte Purkis returns in her chapter to the origins of the Gate Theatre, Dublin. When the company was being set up, Edwards and mac Liammóir derived its name from Peter Godfrey's Gate Studio Theatre in London. However, relatively little is known about the extent of their actual contact with the London Gate or the precise nature of inspiration by its work, and no critical consensus exists on the matter. Purkis meticulously examines the surviving evidence and in the process, she emphasizes the important role of another neglected figure, Velona Pilcher (1894-1952). A visual artist and Godfrey's co-director at London at the time the Dublin Gate was founded, Pilcher was responsible for much of the programming, based on her extensive travels around Europe and in the US, where she went to see productions by a range of avant-garde theatre groups. It was the programming of the London Gate that arguably influenced Edwards and mac Liammóir in their early seasons the most, together with the shared desire to make a 'theatrical', as opposed to illusionist, theatre. Purkis goes on to explore two other related ventures, the Gate Theatre Studio founded in Hollywood in the US in 1943, and the Watergate Theatre Club, which opened in London in 1949. While Godfrey ran the former and Pilcher was involved in establishing the latter, the company members were otherwise mostly different from those at the parent theatre. Purkis uses this loose network to demonstrate how avantgardist theatre operated for several decades of the twentieth century, with individual artists spreading the internationalist outlook and collaborative culture of little theatres across the Western world, representing a prime instance of cultural convergence.

The subsequent five essays focus on a range of mostly neglected productions by the Dublin Gate Theatre that highlight multiple cultural convergences in the theatre's aesthetic, while also frequently teasing out the theatre's politics, about which its directors were certainly (and very likely deliberately) less outspoken than about its artistic aims. Ondřej Pilný discusses the Edwards - mac Liammóir stagings of works by the brothers Čapek - R.U.R. (1921) by Karel and Ze života hmyzu (known to English speakers mostly as The Insect Play, from 1922) written in collaboration with his brother, the celebrated avant-garde painter Josef - and compares them with their original productions in Czechoslovakia. He demonstrates 
how intuitively sensitive Edwards was as a director to the spirit of the original despite the significant discrepancies between the Czech and English play texts (as both Gate productions were based on flawed London adaptations, while The Insect Play was moreover commissioned from the Irish Times satirical columnist Myles na gCopaleen as an intentionally 'Irish' version). Pilný further argues that while the choice of R.U.R. for the Gate's second season in 1929 was due to Edwards and mac Liammóir's strong interest in formally innovative international drama and the global success of the play, the decision to stage The Insect Play - the work of two internationally known anti-fascists - in the throes of World War II (1943) amounted to taking a clear political stance in neutral Ireland. The respective plays were regarded as powerful allegories that spoke to the moment both in Czechoslovakia and in Ireland. However, the meaning of these allegories was constructed by critics and audiences in significantly different ways which had much to do with the atmosphere in the newly independent, optimistic and prosperous Central European republic on the one hand, and that of the also freshly independent but isolationist and economically still largely underdeveloped Irish state on the other.

Elaine Sisson's chapter turns the attention to the fascination with the exotic and the oriental in the early decades of the Gate's existence which, she argues, originated predominantly from popular cinema. Examining the 1931 production of Padraic Colum's Mogu of the Desert, Sisson unravels how the stage and costume design for the play drew upon Hollywood cinematic versions of the West End hit musical Kismet by Edward Knoblock. She points out that Mogu was actually one of a number of productions by Edwards and mac Liammóir from this period that were preceded by film versions screened in Dublin cinemas, such as Wilde's Salomé (1928), Goethe's Faust (1930) and Ibáñez's Blood and Sand (1933), demonstrating the keen awareness of their commercial potential on the part of the Gate's directors. Moreover, Sisson shows how the design language of Mogu buys into contemporary fashion and middle-class bohemian fantasies of the Orient; as such, the design of the production may be interpreted as 'quintessentially modern', featuring a cultural exchange with a range of other forms, high and low: cinema, variety, literature, film magazines and fashion.

The 1934 production of Christa Winsloe's Children in Uniform was also preceded by a successful screen adaptation but on this occasion, the film version - Mädchen in Uniform - would not be shown in Ireland because of its 'difficult theme' (Mandy 14). Yvonne Ivory demonstrates 
once again the intuitive understanding of Hilton Edwards of an original play script to which he had no access: she elucidates how the director of the Gate production not only reinstated details of amorous relationships amongst the female characters that were suppressed both in the film version and in some of the earlier stagings of Winsloe's drama, but also subtly elaborated on the feelings between the central pair of the teacher and her pupil. Ivory's chapter unravels the remarkable feat that it was to stage Children in Uniform with its obvious lesbian subject matter in morally conservative Ireland, and more, to make it a success with audiences and critics alike. She points out that although the reviewers discussed the play mostly as a critique of authoritarianism, they clearly recognized the 'sexual dissidence'. It may be argued then that the Edwards-mac Liammóir production of Children in Uniform only confirmed that, in Ivory's words, "the Boys" had created a haven in the old Rotunda Assembly Rooms for queer expression'.

In the concluding chapter, Erin Grogan focuses on another unduly neglected figure at the Gate, Christine Longford. Grogan concentrates on three of Longford's history plays that were produced during World War II, Lord Edward (1941), The United Brothers (1942) and Patrick Sarsfield (1943), and demonstrates that despite their ostentatious setting in the past, Longford and the Gate were clearly commenting on the war and Ireland's neutrality by producing these works, defying the censorship in a way similar to the Edwards-mac Liammóir staging of The Insect Play discussed by Pilný. Moreover, Grogan argues that Longford's own complicated position as an Englishwoman living in Ireland during the war and being an Irish patriot at the same time made her scrutinize essentialist notions of identity in her war-time history plays, particularly in relation to women. Developing Cathy Leeney's recent work on the playwright and Gate manager (Leeney 2018), Grogan concludes that Longford engaged with the failure of the Irish state to deliver on the promises of gender equality by 'placing women in central positions within politics, bypassing censorship and utilizing historical stories' to critique the contemporary state of affairs.

This volume, then, presents a wide range of translations and transpositions, links and collaborations, engagements and contestations that underline the Gate Theatre's importance to facilitating cultural convergence, which are interpreted not as processes of homogenization or embodiments of a specific telos, but as the complex and versatile dynamics that enable cosmopolitan identity formation. In this sense, it is precisely 
the Gate's ostensible specificity as a Dublin playhouse and its distinctiveness as an Irish theatre company that exemplify the paradoxical nature of cultural individuation, further highlighting what might be termed 'the constitutive multiplicity of Ireland's avant-garde national theatre' (van den Beuken 209). ${ }^{1}$

\section{Note}

1. Work on this chapter was supported by the European Regional Development Fund Project 'Creativity and Adaptability as Conditions of the Success of Europe in an Interrelated World' (No. CZ.02.1.01/0.0/0.0/16_019/0000734).

\section{WORKS CITED}

Canfield, Curtis, ed. 1936. Plays of Changing Ireland. New York: Macmillan.

Cave, Richard. 2016. 'Modernism and Irish Theatre 1900-1940'. In The Oxford Handbook of Modern Irish Theatre. Eds Nicholas Grene and Chris Morash, 121-37. Oxford: Oxford University Press.

Fitz-Simon, Christopher. 2002. The Boys: A Biography of Micheál MacLiammóir and Hilton Edwards. $2^{\text {nd }}$ edn. Dublin: New Island Books.

Foster, R.F. 2014. Vivid Faces: The Revolutionary Generation in Ireland 18901923. London: Allen Lane.

Jordan, Eamonn, and Eric Weitz. 2018. The Palgrave Handbook of Contemporary Irish Theatre and Performance. London: Palgrave Macmillan.

Leeney, Cathy. 2018. 'Class, Land, and Irishness: Winners and Losers: Christine Longford'. In The Gate Theatre, Dublin: Inspiration and Craft. Eds David Clare, Des Lally, and Patrick Lonergan, 161-79. Oxford and New York: Peter Lang/Carysfort Press.

Levitas, Ben. 2014. 'Modernist Experiments in Irish Theatre'. In The Cambridge Companion to Irish Modernism. Ed. Joe Cleary, 111-27. Cambridge: Cambridge University Press.

mac Liammóir, Micheál. 1961. All for Hecuba: An Irish Theatrical Autobiography. Dublin: Progress House.

Mandy, W.J.K. 1932. 'The London Scene'. Motley 1.3: 12-14.

Morash, Chris. 2016. 'Places of Performance'. In The Oxford Handbook of Modern Irish Theatre. Eds Nicholas Grene and Chris Morash, 425-42. Oxford: Oxford University Press.

Ó hAodha, Micheál. 1990. The Importance of Being Micheál. Cooleen: Brandon Book Publishers. 
Reynolds, Paige. 2016. 'Direction and Design to 1960'. In The Oxford Handbook of Modern Irish Theatre. Eds Nicholas Grene and Chris Morash, 201-16. Oxford: Oxford University Press.

Ritzer, George. 2011. Globalization-The Essentials. London: Wiley-Blackwell.

Sisson, Elaine. 2018. 'Experiment and the Free State: Mrs Cogley's Cabaret and the Founding of the Gate Theatre 1924-1930'. In The Gate Theatre, Dublin: Inspiration and Craft. Eds David Clare, Des Lally, and Patrick Lonergan, 11-27. Oxford and New York: Peter Lang/Carysfort Press.

van den Beuken, Ruud. 2020. Avant-Garde Nationalism at the Dublin Gate Theatre, 1928-1940. Syracuse, NY: Syracuse University Press.

Walsh, Ian R. 2018. 'Hilton Edwards as Director: Shade of Modernity'. In The Gate Theatre, Dublin: Inspiration and Craft. Eds David Clare, Des Lally, and Patrick Lonergan, 29-45. Oxford and New York: Peter Lang/Carysfort Press. Walshe, Éibhear. 2016. 'The Importance of Staging Oscar: Wilde at the Gate'. In The Oxford Handbook of Modern Irish Theatre. Eds Nicholas Grene and Chris Morash, 217-30. Oxford: Oxford University Press.

Open Access This chapter is licensed under the terms of the Creative Commons Attribution 4.0 International License (http://creativecommons.org/licenses/ by $/ 4.0 /)$, which permits use, sharing, adaptation, distribution and reproduction in any medium or format, as long as you give appropriate credit to the original author(s) and the source, provide a link to the Creative Commons license and indicate if changes were made.

The images or other third party material in this chapter are included in the chapter's Creative Commons license, unless indicated otherwise in a credit line to the material. If material is not included in the chapter's Creative Commons license and your intended use is not permitted by statutory regulation or exceeds the permitted use, you will need to obtain permission directly from the copyright holder.

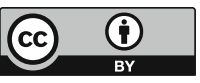

